\title{
Sustainable Growth of Airline Companies: Challenges and Prospects Assessment
}

\author{
T.A. Slepneva ${ }^{1, *}$ and N.V. Svishcheva ${ }^{1}$ \\ ${ }^{1}$ Financial University under the Government of the Russian Federation, Moscow, Russia
}

\begin{abstract}
Due to the sufficient openness of the Russian air transportation market, such factors as demand and investment activity, exchange rate fluctuations, economic sanctions against large companies and other unfavorable conditions lead to a slowdown (sometimes a decrease) in sales growth of Russian companies, weakening their economic position and financial stability. In this regard, it is necessary to study the conditions and opportunities for achieving sustainable growth, based on the example of Russian airlines using econometric modeling methods The solution of this problem requires the study of a system of economic and non-economic factors to achieve sustainable growth. It also requires an analysis of the industry specifics of air passenger transportation market to determine the main indicators of economic growth.
\end{abstract}

Keywords: Airlines growth, Revenue modeling, Sustainable growth, Financial and non-financial growth factors.

\section{Introduction}

Achieving sustainable growth for many companies in any industry, is an important requirement for economic success, especially in the face of falling demand, declining investment activity, currency fluctuations and other unstable economic conditions.

During general economic downturn the lack of sustainable growth has a negative impact on the development of companies, which leads to a decrease in shareholder income and can also lead to bankruptcy of companies. Despite the annual growth in passenger traffic in recent years, this growth cannot be defined as sustainable in the current economic environment, and airlines are experiencing financial difficulties. Since 2014, due to the increasing losses caused by the decline in passenger traffic and the general decline of the Russian economy, the air transport sector has experienced a difficult economic situation. This has had a negative impact on the sustainability and prospects for further development of companies in the industry.

Financial and economic stability and achieving sustainable growth are important conditions for existence and development of many companies in any industry. Sustainability factors are particularly relevant in the context of falling demand, declining investment activity, currency exchange fluctuations and other negative factors (Ponomarenko, Fedoseev, Korotkiy \& Belitskaya, 2016).

*Corresponding author: taslepneva@fa.ru 
The aviation industry is one of the most developing and promising industries, and the profit from transportation is the main source of income for any airline. In 2019 Russian carriers served 128.1 million passengers, which is $10.2 \%$ more than in 2018 . The market leader is PJSC Aeroflot, which transported 59.1 million passengers in 2019. The closest competitor of the Aeroflot Group is S7 Group, which transported 17.9 million passengers, $12 \%$ more than in 2018. Ural Airlines ranks third in terms of passenger traffic, which in 2019 increased passenger traffic by $7 \%$ to 9.6 million people (Aeroflot, 2020).

The Russian market of passenger air transportation is highly consolidated: according to the results of 2019 , the share of the listed airlines accounts for more than $60 \%$ of the total passenger traffic. Flights of foreign airlines in the Russian market in 2019 carried 19.7 million passengers, which is approximately $13 \%$ of the Russian passenger air transportation market.

Airline activity is specific and carries many different risks. One of the main risks is the socio-economic situation in the country where the company operates. Poor social and economic situation relates to instability of political system, presence of armed conflicts, prevalence of various mass diseases. Another important factor in performing business abroad is a high level of insurance coverage of technical resources and passengers. If a region has underdeveloped infrastructure, the airline is obliged to compensate it with its own means of service and maintenance. Instability of the economic situation has a great influence on the demand for air carriers' services, which, first, depends on the mobility of the population. Mobility of the population is characterized by the standard of living, solvency, business activity, intensity of labor migration and others.

Another important feature of the air transportation market is seasonality, which is especially evident during the summer vacation period when the capacity of airlines is fully utilized. There is also a slight increase in demand during the winter vacation period. During periods of decline in service consumption, commercial load factor decreases, and destabilization of cash flow occurs during the year.

The airline industry is highly sensitive to fluctuations of jet fuel prices, since jet fuel costs account for a significant share of airlines' cost of sales. Jet fuel prices are determined by the dynamics of oil and petroleum products prices. Aviation companies also face high operational risks associated with the operation of aircraft as a high-risk vehicle and represent compensations for the onset of adverse events and the severity of their consequences. Safety of flights should be one of the main priorities of any airline, since any incident negatively affects not only the reputation of the air carrier, but also its further functioning. For example, companies "Kogalymavia" and "Tatarstan" went bankruptcy proceedings immediately after the incident of the crash (Bogdanova, 2018).

The main sources of financial risks for airlines are the presence of interest rate and currency risks. Any airline is more likely to finance its operations with borrowed funds (including loans and borrowings, accounts payable, etc. for operational leasing). Changes in interest rates lead to an increase in debt servicing costs and a decrease in the company's profitability.

Currency risk arises due to the dependence of a significant part of airline revenues and expenses on the dynamics of the ruble exchange rate against the Euro and the US dollar. Revenue from the sale of tickets for international flights is either collected or charged in foreign currency (transfer passengers, foreign markets), jet fuel costs, maintenance and leasing payments, payments at foreign airports are denominated and made in foreign currency (Federal air transport Agency, 2020).

The airline's liquidity risk is associated with difficulties in fulfilling its obligations to third parties regarding debt obligations. To reduce the probability of a negative impact of this type of risk, airlines should open current accounts with the most reliable banks with a high reputation. They should also maintain an operational system of control over the use of 
working capital, which allows to identify cash gaps in advance, create a sufficient liquidity reserve, quickly raise funds in the monetary market and make the most of available funds.

The financial analysis of the leading Russian airlines for 2015-2019 showed a high dependence of their operations on borrowed funds: over the past 5 years, the share of borrowed capital in the aggregate averaged $63 \%$. The expansion of activity was mainly financed by increasing liabilities, which indicates that growth is not stable. At the same time, short-term accounts payable prevail as a relatively cheap source with a high level of default risk. As a result, the balance sheet of the analyzed airlines is mainly illiquid, which also confirms the growth instability.

According to the financial statements, revenue growth of the leading Russian airlines has been observed over the past five years. However, the company's operating expenses are growing even faster, which have a significant impact on profit volumes. As a result of reduced profits, companies annually receive less free cash that can be used to finance current and investment activities (Sabaityte, Davidavičiené \& Van Kleef, 2020).

At the same time, the long-term strategy of airline companies is aimed at increasing business activity and shareholders value. However, an increase in business activity does not always lead to the creation of additional value and an increase in the welfare of owners. Practice shows that not every quality of corporate growth contributes to the prosperity of the company in the medium- and long-term time horizons. Unbalanced growth contributes to the accumulation of risks (Khotinskaya \& Chernikova, 2017). The high growth rates of transportation that are common for Russian airlines combined with insufficient own resources may lead to depletion of the company's resources and loss of financial stability as a result of increased debt burden and reduced liquidity. Therefore, the actual growth of the company should correspond to its financial capabilities.

\section{Methodology}

This research is aimed to assess the near-term prospects and quantify the opportunities for Russian airlines to achieve sustainable growth. The aim of the article is to investigate methodological aspects of achieving sustainable growth and to analyze real potential for Russian airlines to achieve sustainable growth.

The research methodology includes descriptive and comparative methods of general scientific knowledge, methods of financial analysis and econometric modeling: regression analysis using the statistical package $\mathrm{R}$. The method of correlation and regression analysis was used to assess the impact of non-financial factors, along with financial ones, on achieving sustainable growth. Based on regression analysis, an econometric model that represents the dependence of the company's sales volume on the values of such factors of sustainable growth as passenger traffic volume, passenger load level, seasonality of operations, profitability of sales, current ratio, assets turnover ratio, debt ratio and cost of non-current assets was created. The method allows to estimate the influence of various company's sustainable growth factors and identify factors that have the greatest impact on the revenue. Understanding these factors allows the company to develop the most rational strategy for its future activities.

The significance of regression coefficient in regression model will be verified using the Student's t-test, determinacy coefficient, Fisher test, and Darbin-Watson test (Dougherty, 2009).

Then the key factor of revenue growth will be determined, and with the help of econometric methods and Monte Carlo simulations the probability of achieving sustainable growth of PJSC "Aeroflot" will be calculated. At the end of the research, some methods of 
increasing passenger traffic of airlines contributing to the growth of passenger traffic and revenue in these crisis conditions are proposed.

The information base of the research is provided by the data of annual reports and financial statements of the largest Russian airlines (PJSC "Aeroflot", S7 Group, JSC "Ural Airlines") for the period 2014-2019.

\section{Results}

To assess whether the growth of airlines corresponds to their potential capabilities the models of sustainable growth of Higgins (Higgins, 1977), BCG (Zakon, 1986), Van Horn, James (Van Horn \& James, 1998), Ulrich, and Arlow (Ulrich \& Arlow, 1980) were used. The purpose of applying the models is to determine the growth rate of the company's sales, which is achievable, on the one hand, with the unchanged operating policy, on the other hand, with a stable financial structure of the company. Sustained growth is the maximum speed at which a company can increase sales without running out of financial resources (Lan, Yang \& Tseng, 2019). This determines the possible growth rate of revenue or profit, which is provided with resources, provided that the key indicators of the company's operating, financial (including dividend) policy are constant (Voloshina, Zaharova, Kartashev, \& Ulanova, 2019).

Calculations of stable growth rates using these models have shown results indicating that the growth of airline revenue in the analyzed period is not stable. Growth is not supported by its own sources of financing, and the company's activity has been characterized by extremely low profitability over the past two years (table 1).

Table 1. Estimation of the actual and sustainable growth of Russian airlines, $\%$

\begin{tabular}{l|c|c|c|c|c|c}
\hline \multirow{2}{*}{ Sustainable growth models } & \multicolumn{3}{|c|}{ Aeroflot Group } & \multicolumn{3}{c}{ S7 Airlines } \\
\cline { 2 - 8 } & 2017 & 2018 & 2019 & 2017 & 2018 & 2019 \\
\hline Revenue growth & $\mathbf{4 . 4}$ & $\mathbf{1 3 . 0}$ & $\mathbf{9 . 3}$ & $\mathbf{3 1 . 5}$ & $\mathbf{8 . 9}$ & $\mathbf{2 3 . 3}$ \\
\hline BCG model & 18.6 & 4.5 & 8.1 & 26.4 & 54.9 & 31.6 \\
\hline Higgins model & 18.2 & 4.6 & 7.6 & 26.1 & 42.5 & 29.8 \\
\hline Van Horne's model & 22.3 & 4.9 & 8.2 & 35.3 & 73.8 & 42.5 \\
\hline Ulrich-Arlow's model & 34.4 & 6.7 & 10.8 & 30.7 & 44.2 & 22.0 \\
\hline
\end{tabular}

Source: Own processing.

Based on the conducted calculations it is possible to identify financial and non-financial indicators of the airlines' stable growth. Financial indicators of sustainable growth are:

- profitability and cost intensity indicators;

- indicators of business activity that assess the intensity of growth. Growth rates analysis based on asset utilization efficiency is carried out by comparing the company's commercial revenue with various operating assets (Makarov, Ryabova \& Hvostova, 2019);

- liquidity and financial stability indicators reflecting the company's financial independence;

- the level of interest rates on liabilities that affect the value and structure of companies' capital;

- the level of inflation and economic growth in the country. In a period of high inflation, companies will have a lower debt ratio, which may lead to underfunding of operating activities (Ramli, Latan \& Solovida, 2019).

The main non-financial factors for the sustainable growth of airlines are: 
- operating results that depend on the industry specifics of the company, such as aircraft load levels, passenger traffic volume, fleet composition, number of flight destinations, etc.;

- the structure of the Board of Directors and the number of independent directors;

- seasonality that affects the company's passenger traffic.

In order to rank and identify key indicators of sustainable growth of Russian airlines, we will conduct a regression analysis of financial and non-financial growth factors.

To identify significant revenue growth factors and assess their impact, we will construct a multiple linear regression model of revenue dependence based on the example of PJSC "Aeroflot". The dependent variable $y_{t}$ - the company's quarterly revenue from 2015 to 2019 , is modeled. Revenue $y_{t}$ is assumed to be affected by non-financial factors, which represent data from the company's operational statistics, as well as artificially modeled fictitious variables.

The main non-financial factors that affect the company's revenue are the volume of passenger traffic $\left(x_{1}\right)$ and the level of passenger loading of the aircraft $\left(x_{2}\right)$. In addition, the company's revenue is seasonal; therefore, three fictitious variables should be entered for quarterly data:

$$
\begin{aligned}
& x_{3}=\left\{\begin{array}{c}
0, \text { in all other cases } \\
1, \text { second quarter data }
\end{array}\right. \\
& x_{4}=\left\{\begin{array}{c}
0, \text { in all other cases } \\
1, \text { third quarter data }
\end{array}\right. \\
& x_{5}=\left\{\begin{array}{c}
0, \text { in all other cases } \\
1, \text { fourth quarter data }
\end{array}\right.
\end{aligned}
$$

Financial indicators of sustainable growth of companies are considered as financial factors in the model: profit before tax return on sales $\left(x_{6}\right)$. current liquidity ratio $\left(x_{7}\right)$. asset turnover ratio $\left(x_{8}\right)$. financial dependency ratio $\left(x_{9}\right)$. volume of non-current assets $\left(x_{10}\right)$.

The parameters of the linear econometric model are estimated using the least squares method. The following regression equation is obtained:

$\hat{y}=-0.140+0.766 x_{1}+0.140 x_{2}-0.059 x_{3}+0.436 x_{4}+0.185 x_{5}+0.091 x_{6}-$ $0.022 x_{7}+0.090 x_{8}+0.175 x_{9}+0.035 x_{10}$

The results of verification the significance of the factors of the obtained model according to the student's criterion are presented in table 2 .

Table 2. Analysis of the significance of multiple linear regression coefficients of PJSC "Aeroflot" revenue from sustainable growth factors

\begin{tabular}{|l|c|c|c|c|}
\hline & Coefficient estimates, $a_{i}$ & Standard Error & t-statistics $\tau_{i}$ & p-value \\
\hline$a_{0}$ & -0.140 & 0.291 & -0.483 & 0.641 \\
\hline$a_{1}$ & 0.766 & 0.153 & 5.018 & 0.001 \\
\hline$a_{2}$ & 0.140 & 0.094 & 1.491 & 0.170 \\
\hline$a_{3}$ & -0.059 & 0.178 & -0.334 & 0.746 \\
\hline$a_{4}$ & 0.436 & 0.351 & 1.244 & 0.245 \\
\hline$a_{5}$ & 0.185 & 0.683 & 0.270 & 0.793 \\
\hline$a_{6}$ & 0.091 & 0.096 & 0.950 & 0.367 \\
\hline$a_{7}$ & -0.022 & 0.063 & -0.346 & 0.737 \\
\hline$a_{8}$ & 0.090 & 0.372 & 0.242 & 0.814 \\
\hline$a_{9}$ & 0.175 & 0.071 & 2.455 & 0.036 \\
\hline$a_{10}$ & 0.035 & 0.051 & 0.693 & to 0.506 \\
\hline
\end{tabular}

Source: Own processing based on student's t-test used.

The lower is the p-value for the coefficient $a_{i}$, the higher is the absolute value of the tstatistics for the coefficient and the lower is the probability that this coefficient is equal to 
0 . That is, the hypothesis that the coefficient is equal to 0 and the factor is not significant in the model is rejected. Therefore, it is necessary to exclude factors with p-value greater than 0.05 in turn.

As a result of alternately excluding insignificant factors, the following regression equation is obtained:

$$
\hat{y}=0.865 x_{1}+0.163 x_{4}+0.191 x_{6}+0.179 x_{9}
$$

Let us check the significance of the final model coefficient estimates using the Student's criterion. The data is presented in table 3 .

Table 3. Analysis of the significance of multiple linear regression coefficients of PJSC Aeroflot's revenue from sustainable growth factors

\begin{tabular}{|c|c|c|c|c|}
\hline & Coefficient estimates. $a_{i}$ & Standard error & t-statistics. $\tau_{i}$ & p-value \\
\hline$a_{1}$ & 0.865 & 0.036 & 24.168 & $<0.0001$ \\
\hline$a_{4}$ & 0.163 & 0.043 & 3.782 & $<0.0005$ \\
\hline$a_{6}$ & 0.191 & 0.039 & 4.835 & $<0.0005$ \\
\hline$a_{9}$ & 0.179 & 0.041 & 4.417 & 0.002 \\
\hline
\end{tabular}

Source: Own processing based on student's t-test used.

The calculated values of t-statistics for each coefficient $a_{i}$ are greater than the critical one. Therefore, all factors are significant in this model. Also, all coefficients $a_{i}$ for factors are positive, consequently, there is a direct relationship between factors and company revenue. Thus, significant factors for sustainable growth of revenue of PJSC "Aeroflot" are:

- passenger traffic volume $\left(x_{1}\right)$ is the main factor with the largest contribution to revenue;

- the seasonal factor that characterizes revenue in July, August and September $\left(x_{4}\right)$ indicates that it is during these months that there is a high demand for air tickets, and the company can implement various measures to increase revenue with great economic success;

- return on sales by profit before tax $\left(x_{6}\right)$ - a factor that indirectly characterizes the pricing policy or strategy for optimizing operating expenses;

- financial dependency ratio $\left(x_{9}\right)$ - the higher the financial dependency ratio and therefore the amount of borrowed capital, the higher the revenue volume should be for the company to function sustainably.

The determination coefficient for this model is 0.9882 . It means that $98.82 \%$ of the initial process variability is considered by the created model. The calculated value of Fischer statistics is 313.1. The P-value of this statistic is less than 0.001 , therefore, the model is significant and explains the initial process well, and the role of factors in explaining the variability of the analyzed process is essential. Verification of the presence of first-order autocorrelation in the $D W$ error row using the Darbin-Watson criterion has shown that the values of the $D W$ criterion are $\approx 1.7924$. Consequently, the 1 st-order autocorrelation coefficient $\rho_{1}=0$. We can conclude that first-order autocorrelation in the error series is rather not observed.

Analyzing the quality criteria of the model created for PJSC "Aeroflot" quarterly revenue volume, it can be concluded that the model generally describes the initial process well. The main factors of sustainable revenue growth are the airline's passenger traffic volume, seasonal factor and the return on sales. The impact on these factors can help airlines achieve sustainable growth. 


\section{Discussion}

The modeling of revenue dependency by the example of PJSC "Aeroflot" has revealed an increase in passenger traffic as a key driver of revenue growth. Calculation of the probability of achieving the range of revenue growth values in the forecast year, calculated at the estimated cost of sales and given levels of profitability, is performed using econometric methods of creating PJSC "Aeroflot" revenue model with seasonal component and Monte Carlo simulation method based on quarterly revenue data for 2015-2019 (table 4). According to the results of the study, it is unlikely that steady revenue growth rates will be achieved in the forecast year.

Table 4. Probability of achieving different revenue growth rates for PJSC Aeroflot in 2020 by 2019

\begin{tabular}{|c|c|c|c|}
\hline Return on sales, $\%$ & Revenue, thousand rubles & Growth rate by 2019, $\%$ & Probability, \% \\
\hline 0 & 613856737 & 11.3 & 39.9 \\
\hline 0.5 & 616941444 & 11.8 & 37.1 \\
\hline 1 & 620057310 & 12.4 & 34.2 \\
\hline 2 & 626384425 & 13.5 & 28.2 \\
\hline 3 & 632841996 & 14.7 & 21.1 \\
\hline 4 & 639434101 & 15.9 & 12.4 \\
\hline 5 & 646164986 & 17.1 & 4.7 \\
\hline 6 & 653039081 & 18.4 & 0.0 \\
\hline
\end{tabular}

Source: Own processing based on the Monte Carlo method.

In addition, it was found that COVID-19 pandemic development in 2020 may be the reason of unprofitable operating process of airlines. Since March 27, 2020 Russian airlines have stopped almost all scheduled and charter flights abroad (Moscow: RBC, 2020). This situation will lead to significant losses for Russian airlines. At full stop of international flights, airlines certainly will not bear variable costs at the same level (kerosene, airport taxes, passenger service, air navigation services). At the same time, income from international transportation cannot cover losses that arise on domestic flights, so the probability of losses in 2020 is exceedingly high. Moreover, the cancellation of international flights leads to a reduction in transfer passenger traffic within the country.

The International Air Transport Association (IATA) estimates that global passenger airline revenues will fall by $55 \%$, or $\$ 314$ billion, in 2020 as a result of severe restrictions on air travel (Moscow: Interfax, 2020). Overall, the demand for passenger transportation will drop by $48 \%$ in 2020 due to bans and the economic consequences of the crisis, as a result of increased unemployment and a significant decline in income.

According to experts' forecasts, Russian airlines may lose 550 billion rubles of revenues in 2020, if the current situation with air services will remain until the end of June and demand at the level of 2019 will recover only by December 2020, and the ban on international flights will last until the end of July and demand for them will recover only to $60 \%$ of last year's figures (Moscow: Vedomosti, 2020).

In order to increase airline sales in the current environment, the following possible measures can be proposed to influence the factors of sustainable revenue growth: changes in airline pricing policy and increase passenger traffic.

However, the low profitability of companies in 2018-2019 and the reduction of passenger traffic in 2020 lead to the impossible pricing policy aimed at reducing the cost of tickets. In 2018, rising kerosene prices cost air carriers more than 50 billion rubles of additional costs. Currency risks are another reason of impossibility to reduce air ticket prices Lease payments and the cost of servicing the company's aircraft fleet are increasing due to the weakening of the ruble. The reason of this situation is that costs are either 
denominated in foreign currency or calculated in rubles, but at the dollar rate. Under the conditions of instability of the ruble, this leads to instability of operating expenses. The third reason is weather conditions, which imply an increase in airline costs during the five months from November to March of each year, which prevents airlines from reducing the cost of tickets currently. Fourthly, with the spread of coronavirus infection in 2020 and a dramatic decline in the number of flights, airlines are now selling tickets at prices that only cover the cost of fuel, airport services and navigation (Moscow: Kommersant, 2020).

Consequently, it is not possible to reduce air ticket prices. Moreover, it is difficult to maintain prices at current levels as operating costs are decreasing slightly and slightly depending on the airlines' operational and financial policies.

The following measures may be offered to companies as the main ways to increase passenger traffic:

- increasing the number of air transportation destinations by expanding the list of new destinations and increasing flights to existing locations;

- expansion of the air fleet and modification of the aircraft interior;

- cooperation with entertainment companies in different countries in terms of obtaining the opportunity to visit a cultural and entertainment center when purchasing an air ticket of the company;

- changes in luggage fare policy in terms of introducing a progressive luggage fare scale (Augusto, Godinho \& Torres, 2019).

\section{Conclusion}

In order to achieve sustainable growth and increase in value, companies need to balance the key factors of sustainable growth with the key indicators of operational, investment and financial performance. The study identified key financial and non-financial factors for sustainable growth of airlines and proposed several measures to manage these factors, which is practically important for both for individual companies and for the entire airline sector.

Based on the research, it can be concluded that despite the positive dynamics, the growth of Russian airlines in recent years is not sustainable and will not become sustainable in the near future, which is due to the specifics of airline operations and the consequences of the pandemic. In 2020, the situation in the airline industry is characterized as a very difficult one, in which airlines cannot operate without financial support from the government. Companies are also forced to implement additional measures to increase revenues by influencing sustainable growth factors in all possible ways in the face of a significant reduction in demand. To achieve sustainable growth, airlines need to increase operating revenues, primarily by influencing growth factors such as passenger traffic. Implementing proposed ways to attract new customers can help airlines increase sales.

\section{References}

1. Augusto, M., Godinho, P. \& Torres P. (2019). Building customers' resilience to negative information in the airline industry. Journal of retailing and consumer services, 50, 235-248.

2. Bogdanova, M. P. (2018). Specifica razvitiya kompanii "Aeroflot" v usloviyah krizisa otrasli (Specifics of development of the company "Aeroflot" in the context of the industry crisis). Business strategy, 10(54), 13-17. 
3. Dougherty, C. (2009). Vvedenie v ekonometriku (Introduction to econometrics). Moscow: INFRA-M. 465.

4. Federal'noe agentstvo vozdushnogo transporta (Federal air transport Agency). (2020). Available at: https://www.favt.ru/novosti-novosti/?id=6026. (accessed: 27 August 2020).

5. Godovoy otchet PAO "Aeroflot" za 2018 god (Aeroflot's annual report for 2018). (2020). Available

at: https://ir.aeroflot.ru/fileadmin/user_upload/files/rus/reports/annual_reports/aeroflot_ar1 8_rus.pdf. (accessed: 27 August 2020).

6. Higgins, R.C. (1977). How much growth can a firm afford? Financial Management, 6(3), 7-16.

7. Khotinskaya, G.I. \& Chernikova, L.I. (2017). Empirical characteristics of Russian business growth. Academy of Strategic Management Journal, 16(2), 19.

8. Lan, S., Yang, C. \& Tseng, M.-L. (2019). Corporate sustainability on causal financial efficiency model in a hierarchical structure under uncertainties. Journal of Cleaner Production, 237, 117769.

9. Makarov, A.S., Ryabova, E.V. \& Hvostova, I.E. (2019). Problemy sovershenstvovaniya finansovyh metodov i modeley obespecheniya ustoychivogo razvitiya kompanii (Problems of improving financial methods and models for sustainable development of the company). Moscow: INFRA-M. 175.

10. Ponomarenko, T.V., Fedoseev, S.V., Korotkiy, S.V. \& Belitskaya, N.A. (2016)/ Managing the implementation of strategic projects in the industrial holding. Indian Journal of Science and Technology, 9, 14, 91517.

11. Profil'naya associaciya sprognozirovala padenie vyruchki aviakompaniy na $55 \%$ (The profile Association predicted a 55 drop in airline revenue \%). (2020). Interfax. Available at: https://www.interfax.ru/world/704154. (accessed: 27 August 2020).

12. Ramli, N.A., Latan, H. \& Solovida, G.T. (2019). Determinants of capital structure and firm financial performance-A PLS-SEM approach: Evidence from Malaysia and Indonesia. The Quarterly Review of Economics and Finance, 71, 148-160.

13. Rossiya ostanovit regulyarnye i charternye polyoty zarubezh (Russia will stop regular and Charter flights abroad). (2020). RBC. Available at: https://www.rbc.ru/society/26/03/2020/5e7c3c2e9a79474c9ad04dc7 (accessed: 27 August 2020).

14. Rossiyskie aviakompanii riskuyut poteryat' poltrilliona rubley iz-za epidemii (Russian airlines risk losing half a trillion rubles due to epidemic). (2020). Vedomosti. Available at: https://www.vedomosti.ru/business/articles/2020/04/30/829368-rossiiskieaviakompanii (accessed: 27 August 2020).

15. Sabaityte, J., Davidavičiené, V. \& Van Kleef, G.F. (2020). The peculiarities of lowcost carrier development in Europe. Energies, 13, 3, 639.

16. Ulrich, T. \& Arlow. P. (1980). The Financial Implications of Growth. Journal of Small Business Management, 27(2), 28-33.

17. Van Horn, J.C. \& James. C. (1998). Sustainable growth modeling. Journal of Corporate Finance, 1, 19-25.

18. Vladelec S7 Vladislav Filev o pravilah igry vo vremya epidemii (S7 owner Vladislav Filev about the rules of the game during the epidemic). (2020). Kommersant. Available at: https://www.kommersant.ru/doc/4328432?from=doc_vrez. (accessed: 27 August 2020).

19. Voloshina, A.I., Zaharova, E.D., Kartashev, M.A. \& Ulanova, N.K. (2019). Upravlenie determinantami ustoychivogo rosta (Managing the determinants of sustainable growth). Economics and Business: Theory and Practice, 5(1), 109-112.

20. Zakon, A. (1986). Growth and financial strategies. Boston: Boston Consulting Group. 